\title{
MOTIVASI DAN PERILAKU PERAWAT DALAM PENCEGAHAN INFEKSI NOSOKOMIAL PLEBITIS DI RUANG BEDAH RS ADI HUSADA SURABAYA
}

\author{
DEWI ANDRIANI \\ AKADEMI KEPERAWATAN ADI HUSADA SURABAYA \\ andridewi64@gmail.com
}

\begin{abstract}
ABSTRAK
Infeksi nosokomial merupakan infeksi silang yang terjadi akibat perpindahan mikroorganisme melalui petugas kesehatan dan alat yang dipergunakan saat melakukan tindakan. Plebitis merupakan inflamasi vena yang disebabkan baik oleh iritasi kimia maupun mekanik. Perilaku perawat dalam melakukan pemasangan infus yang tidak sesuai standart operasional dapat mengakibatkan terjadinya infeksi nosokomial plebitis. Penelitian ini bertujuan untuk mengidentifikasi motivasi dan perilaku perawat dalam pencegahan infeksi nosokomial plebitis pada saat pemasangan infus. Desain penelitian yang digunakan adalah analitik korelasional. Variabel dependen adalah motivasi dan variabel independen adalah perilaku perawat dalam pencegahan infeksi nosokomial plebitis. Pengumpulan data menggunakan kuesioner dan observasi. Jumlah responden 30 orang. Teknik pengambilan sampel adalah purposive sampling. Hasil uji statistik Spearman Rank Test menunjukkan $\mathrm{p}=0.01(\alpha<0.05)$ dan $\mathrm{r}=0.857$, sehingga terdapat hubungan yang bersifat kuat antara motivasi dan perilaku perawat dalam pencegahan infeksi nosokomial di Ruang Bedah RS Adi Husada Undaan. Semakin tinggi motivasi akan semakin baik perilaku perawat melakukan pemasangan infus sesuai standart operasional untuk mencegah terjadinya plebitis. Kondisi ini harus dipertahankan dan ditingkatkan dengan pendidikan dan pelatihan mengenai terapi infus sehingga terjadinya infeksi nosokomial dapat dihindari.
\end{abstract}

Kata kunci: motivasi, perilaku, pencegahan infeksi nosokomial

\begin{abstract}
Nosocomial infections are infections that occur as a result of cross-transfer of microorganisms through health workers and tools used when performing the action. Plebitis is an inflammation of a vein caused by either chemical or mechanical irritants. The behavior of nurses in infusion incompatible operating standards could result plebitis nosocomial infection. This study aims to identify the motivations and behaviors of nurses in the prevention of nosocomial infection plebitis at the time of infusion. The study used analytic correlational design. The dependent variable was motivation and the independent variable was behavior of nurses in plebitis nosocomial infections prevention. Collecting data used questionnaires and observation. The number of respondents were 30 people. The sampling technique was used purposive sampling. Results of statistical test Spearman rank test showed that $p=0.01(\alpha<0.05)$ and $r=0.857$ so there was a strong relationship between motivation and behavior of nurses in the prevention of nosocomial infection in a hospital operating room Adi Husada Undaan. The higher the motivation, the better the behavior of the nurses perform operations according to standard infusion to prevent plebitis. This condition should be maintained and enhanced by education and training on infusion therapy so that the occurrence of nosocomial infections can be avoided.
\end{abstract}

Keywords: motivation, behavior, nosocomial infection preventions 


\section{PENDAHULUAN}

Infeksi nosokomial merupakan infeksi silang yang terjadi akibat perpindahan mikroorganisme melalui petugas kesehatan dan alat yang dipergunakan saat melakukan tindakan. Infeksi nosokomial dikenal pertama kali pada tahun 1847 oleh Semmelweis dan hingga saat ini tetap menjadi masalah yang cukup menyita perhatian sejak tahun 1950 infeksi nosokomial mulai diteliti di berbagai negara dengan sungguh-sungguh terutama di Amerika serikat dan Eropa. ${ }^{4}$ Penderita yang sedang dalam proses asuhan keperawatan di rumah sakit secara umum keadaannya tidak/ kurang baik, sehingga daya tahan tubuhnya menurun. Hal ini mempermudah terjadinya infeksi nosokomial. Di rumah sakit masih sering ditemukan perawat dalam memberikan asuhan keperawatan tidak sesuai standar prosedur yang telah ditetapkan, misalnya tidak menghiraukan hal-hal kecil seperti mencuci tangan sebelum dan sesudah tindakan, tidak menggunakan sarung tangan, menggunakan kembali jarum yang sama setelah digunakan untuk menusuk dalam pemasangan infus. menumbuhkan motivasi kerja perawat, tidak semudah yang di perkirakan.

Motivasi adalah hal yang menyebabkan, menyalurkan, dan mendukung perilaku manusia supaya mau bekerja giat dan antusias mencapai hasil yang optimal. Motivasi bagi perawat semakin penting karena manajer membagikan pekerjaan pada bawahannya untuk dikerjakan dengan baik dan terintegrasi kepada tujuan yang diinginkan.Permasalahannya adalah, pimpinan yang mendorong seorang perawat bekerja sangat bervariasi dan berbeda kapabilitasnya satu dengan lainnya.Hal ini dapat dilihat dalam satu unit keperawatan, ada perawat yang rajin dan tekun dalam bekerja, sangat produktif dan mempunyai kemampuan tinggi dalam menyelesaikan tugas dan tanggung jawabnya dalam memberikan asuhan keperawatan.Sebaliknya ada perawat yang malas, dan kurang memiliki semangat dan gairah kerja, sehingga produktivitas kerja rendah.

Berdasarkan hasil studi yang telah di lakukan di RSUP Dr.Hasan Sadikin Bandung, data yang ditemukan dari tim pengendalian infeksi rumah sakit pada tahun 2010 yaitu kejadian plebitis menempatai infeksi nosokomial tertinggi dengan proporsi $53,42 \%$ dari semua infeksi di rumah sakit tersebut. Data yang telah ditemukan dalam penelitian diruang rawat bedah umum kelas III (KANA) yaitu pada tahun 2010 pada enam bulan terakhir kejadian plebitis terjadi $8,64 \%$ dan pada tahun 2011 sekitar 2,25\%. Sedangkan angka kejadian plebitis di ruang rawat bedah wanita (Kemuning Lantai 3) pada tahun 2010 selama enam bulan terakhir yaitu $1,87 \%$. Angka ini masih berada di atas standar yang telah ditetapkan oleh Menteri Kesehatan RI yaitu dibawah atau sama dengan $1,5 \% .^{5}$

Berbagai cara telah dilakukan untuk mencegah tejadinya infeksi nosokomial plebitis, penyebab dari infeksi nosokomial plebitis dapat diperoleh dari beberapa faktor diantaranya kepekatan cairan atau obat, keseimbangan antara ukuran dan tempat kanule dimasukkan, lamanya pemasangan jalur intravena, tehnik pemasangan dan perawatan pasca pemasangan kanule pada terapi intravena. Akibat dari kejadian phlebitis ini dapat menimbulkan masalah pada ketidaknyamanan pasien, penggantian katheter baru, menambah lama perawatan, dan akan menambah biaya perawatan. Komplikasi yang ditimbulkan dari pemasangan infus, antara lain: Hematoma, tromboflebitis, emboli udara dan plebitis vena. ${ }^{3}$ Dari data tersebut komplikasi yang paling banyak ditemui adalah plebitis, terjadi $75 \%$ pada pasien yang dirawat.

Infeksi nosokomial plebitis sangat merugikan pasien dan meski telah banyak hal telah dilakukan untuk mencegahnya masih saja angka kejadian plebitis tetap ada.Perilaku perawat saat pemasangan infus sangat berpengaruh pada pencegahan infeksi nosokomial plebitis maka hal ini dipandang perlu adanya solusi untuk mencegah infeksi nosokomial plebitis antara lain dengan menjaga kebersihan tangan, pemilihan lokasi vena, mempertahankan tehnik aseptik selama insersi intravena kateter, mengobservasi area dipasangnya kateter infus, penggantian set kateter intravenaserta balutan pada lokasi IV setiap 48-72 jam, serta bila perlu dilakukan pendidikan dan pelatihan mengenai terapi infus. Tujuan penelitian ini adalah mengidentifikasi hubungan motivasi dengan perilaku perawat dalam pencegahan infeksi nosokomial plebitis pada saat pemasangan infus di Ruang Bedah RS Adi Husada Undaan Surabaya. 


\section{METODE}

Penelitian ini menggunakan desain analitik korelasional dengan pendekatan cross-sectional. Teknik pengambilan sampel adalah purposive sampling. Variabel motivasi dan perilaku perawat dalam pencegahan infeksi nosokomial plebitis. Pengumpulan data menggunakan kuesioner dan observasi. Penelitian ini dilakukan di Ruang bedah Rumah Sakit Adi Husada Undaan, pada bulan April-Juni 2014.

Populasi penelitian Perawat di ruang bedah Rumah Sakit Adi Husada Surabaya yang berjumlah 32 orang. Sampel : perawat di ruang bedah Rumah Sakit Adi Husada Undaan Surabaya yang tidak bertugas malam dan tidak sedang cuti berjumlah 30 orang. Analisis data menggunakan uji korelasi rank spearman dengan $\alpha=0.05$.

HASIL

Data Umum

Tabel 1 Karakteristik Responden

\begin{tabular}{llrrrr}
\hline No & Karakteristik & Mean & SD & Min & Maks \\
\hline 1 & Lama kerja & 10.6 & 7.27 & 1 & 24 \\
\hline 2 & Umur & 31.96 & 7.62 & 22 & 46 \\
\hline
\end{tabular}

Tabel 1 menunjukkan lama kerja perawat di ruang bedah Rumah Sakit Adi Husada Undaan adalah 10.6 tahun dan ratarata berumur 31.96 tahun.

Data Khusus

Tabel 2 Tabulasi variabel motivasi dan perilaku pencegahan

\begin{tabular}{llllllll}
\hline \multirow{2}{*}{ No } & Variabel & \multicolumn{2}{c}{ Kurang } & \multicolumn{2}{c}{ Cukup } & \multicolumn{2}{c}{ Baik } \\
\cline { 3 - 8 } & & n & \% & n & \% & n & \% \\
\hline 1 & Motivasi & 0 & 0 & 6 & 20 & 24 & 80 \\
\hline 2 & Perilaku & 0 & 0 & 10 & 33 & 20 & 67 \\
& pencegahan
\end{tabular}

Tabel 2 menunjukkan sebagian besar responden memiliki motivasi yang baik yaitu 24 orang (80\%) dan memiliki perilaku pencegahan infeksi nosokomial yang baik yaitu 20 orang $(67 \%)$ dan setelah diuji statistik menggunakan Spearman Rank Test, menunjukkan hasil terdapat hubungan yang kuat antara motivasi dengan perilaku perawat dalam pencegahan infeks nosokomial phlebitis pada pemasangan infus yaitu $p=0.01(\alpha<0.05)$ dan $r=0.857$.

\section{PEMBAHASAN}

Perilaku perawat dalam melakukan pemasangan infus katagorinya baik karena perawat yang berumur rata-rata 31.96 tahun memiliki perilaku yang cukup. Hal ini dikarenakan umur dapat mempengaruhi perilaku, karena dengan bertambahnya umur seorang perawat akan memiliki tingkat kedewasaan dan pemikiran yang lebih matang dari pada perawat yang masih muda. Perawat yang bekerja 1-5 tahun memiliki perilaku yang cukup, dibandingkan dengan perawat yang memiliki lama kerja 6-20 tahun memiliki perilaku baik, hal ini karena lama kerja sesorang akan mempengaruhi perilaku seseorang untuk lebih berhati hati, karena dengan lama kerja tersebut seseorang akan mempunyai kesempatan yang lebih sering dalam melakukan tindakan keperawatan pemasangan infus karena merupakan tindakan invasive yang dapat menimbulkan resiko komplikasi pada pasien, sehingga perawat yang lebih lama bekerja skill yang dimiliki akan lebih baik. Sikap perawat adalah pernyataan dan reaksi perawat terhadap obyek atau peristiwa melalui stimulus yang melahirkan perasaan mendukung dan sebaliknya. Sikap perawat terhadap pencegahan phlebitis adalah reaksi perawat berupa respon positif maupun negatif terhadap kejadian phlebitis dan kesadaran perawat dalam upaya pencegahan phlebitis di rumah sakit untuk meningkatkan mutu pelayanan. ${ }^{6}$ Sikap perawat dalam usaha pencegahan phlebitis antara lain:

1. Kesadaran perawat untuk selalu melakukan cuci tangan sebelum dan sesudah tindakan.

2. Memperhatikan sterilisasi alat.

3. Melakukan tindakan pemasangan infus seauai tahapan SOP.

4. Melakukan edukasi pada pasien yang terpasang infus untuk tidak melakukan pergerakan yang berlebihan pada daerah yang terpasang infus.

5. Melakukan perawatan infus setiap hari.

6. Perhatikan pengenceran obat untuk terapi intravena.

7. Melakukan observasi pada daerah pemasangan infus, untuk mengetahui tanda -tanda phlebitis.

8. Mengganti balutan infus setiap 24 jam.

9. Perhatikan tanggal dan lama pemasangan, ganti infus pada hari ke tiga untuk mencegah kejadian phlebitis. ${ }^{9}$ 


\section{SIMPULAN}

Berdasarkan hasil penelitian hubungan motivasi perawat dengan Perilaku Perawat Dalam Pencegahan Infeksi Nosokomial Plebitis Pada Saat Pemasangan Infus Di Ruang Bedah RS Adi Husada Undaan Wetan Surabaya dari 30 responden yang diteliti dapat disimpulkan terdapat hubungan yang kuat antara motivasi dengan perilaku perawat dalam pencegahan infeksi nosokomial plebitis pada pemasangan infus.

\section{SARAN}

Undaan Wetan Surabaya tetap mempertahankan perilaku yang sudah ada dan lebih memperhatikan tindakan untuk menyiapkan peralatan secara lengkap, cuci tangan 6 tahap sebelum melakukan pemasangan infus.

\section{DAFTAR PUSTAKA}

1. Alimul.Aziz. 2003. Riset Keperawatan dan Teknik Penulisan Ilmiah. Jakarta: Salemba Medika.

2. Asmadi. 2009. Tehnik Prosedural Keperawatan Konsep dan Aplikasi Kebutuhan Dasar Klien. Jakarta: Salemba Medika.

3. Bruner \& Suddart. 2001. Keperawatan Medikal Bedah. edisi VII. Jakarta: EGC.

4. Darmadi. 2008. Infeksi Nosokomial: Problematika dan Pengendaliannya. Jakarta: Salemba Medika.

5. Depkes. 2007. Pedoman Pencegahan dan Pengendalian Infeksi di Rumah Sakit dan Fasilitas Pelayanan Kesehatan Lainnya. Jakarta

6. Djojosugito MA, Roeshadi D, Pusponegoro AD, Supardi. 2001. Buku Manual Pengendalian Infeksi Nosokomial di Rumah Sakit. Jakarta: Depkes RI.

7. Ducel, G. et al. 2002. Prevention of Hospital-Acquired Infections, A practical guide. 2nd ed. World Health Organization. Department of Communicable disease, Surveillance and Response.

8. Notoatmodjo, Soekidjo. 2010. Ilmu perilaku kesehatan. Jakarta : PT. RienekaCipta.

9. Potter, Patricia A. 2005. Fundamental Keperawatan Volume 1. Jakarta: EGC.
10. Rohani dan Setio. 2010. Panduan Praktik Keperawatan Nosokomial. Jakarta: PT Citra Aji.

11. Sunaryo. 2004. Psikologi untuk keperawatan. Jakarta: EGC 